\title{
Anatomical characteristics and enzymes of the sucrose metabolism and their relationship with latex yield in the rubber tree (Hevea brasiliensis Muell. Arg.)
}

\author{
Alessandro Carlos Mesquita ${ }^{1}$, Luiz Edson Mota de Oliveira ${ }^{1 *}$, Paulo Mazzafera ${ }^{2}$ and Nelson Delú-Filho ${ }^{3}$ \\ ${ }^{1}$ Departamento de Biologia, Setor de Fisiologia Vegetal/UFLA, 37200-000, Lavras, MG, Brasil; ${ }^{2}$ Departamento de Fisiologia Vegetal, \\ Instituto de Biologia, Unicamp; ${ }^{3}$ Laboratório de Biotecnologia/UNINCOR, 37410-000, Três Corações, MG, Brasil. *Corresponding author: \\ ledson@ufla.br
}

Received: 16/05/2006, Accepted: 15/07/2006

Rubber production is dependent on the availability of carbohydrates in the tissues engaged in latex synthesis. In this study three rubber tree clones were used to study the protein profile, the activities of invertase and sucrose synthase in the latex and anatomical characteristics of the bark, as well as to establish a possible relationship with latex production. The clones used in the study, RRIM 600, GT 1 and Fx2261, differed in latex productivity, from high to low in this order. Although present, few differences were observed in the latex protein profile obtained by denaturing electrophoresis. The activity of neutral invertase was higher than the acidic isoform, and both activities were higher in the most productive clones RRIM 600 and GT 1. The same was observed for sucrose synthase but it is suggested that invertase may play a more important role in sucrose cleavage in the latex. The anatomical measurements showed that the number of lactiferous cells and lactiferous rings per $\mathrm{mm}^{2}$, and lactiferous cell diameter were higher only in the most productive clone RRIM 600. Together, invertase activity and anatomical measurements might be useful to distinguish highly productive rubber tree clones.

Key words: Hevea brasiliensis, invertase, lacticiferous vessels, latex, rubber, sucrose synthase.

Características anatômicas e enzimas do metabolismo de sacarose, e sua relação com o a produção de látex na seringueira: A produção de borracha é dependente da disponibilidade de carboidratos nos tecidos envolvidos na produção de látex. Neste estudo em três clones de seringueira foram estudados o perfil protéico, as atividades das enzimas invertase e sacarose sintase no látex e características anatômicas da casca, e tentou-se estabelecer uma correlação com a produção de látex. Os três clones usados no estudo, RRIM 600, GT 1 e Fx2261, diferem na produção de látex, de alta para baixa, nesta sequência. Apesar de serem observadas, foram poucas as diferenças entre os perfis de proteínas do látex, obtidos por eletroforese desnaturante. A atividade de invertase neutra foi maior que a isoforma acídica, e ambas foram maiores nos clones mais produtivos, RRIM 600 e GT 1. O mesmo foi observado para sacarose sintase mas foi sugerido que invertase desempenha papel mais importante na quebra de sacarose no látex. As medidas anatômicas mostraram que o número de vasos laticíferos e de anéis laticíferos por $\mathrm{mm}^{2}$, e o diâmetro dos vasos laticíferos eram maiores somente nas plantas do clone mais produtivo RRIM 600. Juntos, a atividade de invertase e as medidas anatômicas parecem ser parâmetros que poderiam ser usados na identificação de clones de seringueiras altamente produtivos em látex.

Palavras-chave: Hevea brasiliensis, borracha, invertase, látex, sacarose sintase, vasos laticíferos.

\section{INTRODUCTION}

Latex production in rubber trees [Hevea brasiliensis (Willd. ex Adr. de Juss.) Müell. Arg.] is dependent, among other factors, on the availability of carbohydrates in the tissues engaged in latex synthesis (Tupý, 1988). The metabolic processes involved in latex biosynthesis are controlled by some essential metabolic steps which involve the loading of sucrose in the lactiferous vessels and the regulation 
of enzyme activities for latex synthesis. Other important aspects of latex production involve the energy requirement for its biosynthesis and the mechanism concerned with the senescence phenomena, imposed by panel parching and the generated stress which may produce toxic molecules such reactive oxygen species.

Plants display a natural hierarchy of the sink organs regarding the use of photoassimilates (Wardlaw, 1990). In the case of the rubber tree, partition of photoassimilates seems to be more complex since bleeding may be considered an artificial sink relative to the natural sinks of the plant (Tupý, 1988; Amalou et al., 1992). The H. brasiliensis rubber is a polyterpene formed by 5,000 to 10,000 isoprene units organized in an unbranched chain (Kush, 1994), which clearly shows the high demand for photosynthetically fixed carbon.

In the conversion of sucrose to latex in the lactiferous vessels of the rubber tree, the relationship between the rubber produced and metabolic energy necessary to drive the process seems to be very important although additional energy consumption occurs in other cell processes. That relationship seems to be strongly influenced by the clone, season of the year and bleeding system (Tupý, 1988). It is estimated that for every $100 \mathrm{~mL}$ of latex obtained during tapping, corresponding to $50 \mathrm{~g}$ of dry rubber and approximately $1.2 \mathrm{~g}$ of protein, 3 days are necessary for latex regeneration (Jacob, 1970; Pujade-Renaud et al., 1994). Evidently there would be an intense glycolysis demand for rubber biosynthesis as well as for the maintenance of the basal metabolic machinery necessary to produce energy requirements. Therefore it is unquestionable to regard latex production as a very strong sink and enzymes responsible for sucrose cleavage may play a role in this process.

Several reports have indicated that rubber biosynthesis is strongly regulated by sucrose as a limiting factor in sink regions (Moraes et al., 1978; Tangpakdee et al., 1997). Additionally, these reports suggested that the flow of sucrose to the lactiferous cells is regulated by its hydrolysis, thereby involving the enzymes responsible for its synthesis and degradation. Susy cleaves sucrose reversibly to UDPG and fructose, while invertases cleave sucrose irreversibly to fructose and glucose. A number of reports have indicated these enzymes as responsible for the flow and hydrolysis of sucrose in sink tissues (Sturm, 1999; Nguyen-Quoc and Foyer, 2001).

Bouteau et al. (1999) showed that a $\mathrm{H}^{+}$-sugar symport system located in the plasma membrane of laticifers revealed a high capacity to take up sucrose and a variety of other sugars such as oligosaccharides from the raffinose family. A $1 \mathrm{mM}$ sucrose affinity was found for the symport.

Moraes et al. (1978) reported that tapping stimulated latex production in native rubber trees which was followed by a decrease in sucrose. They also reported data from the Ivory Coast, Africa, supporting their data.

The effect of tapping on the activity of invertase was shown by Tupý (1973a) who observed that the activity of invertase was several times higher in tapped rubber trees than untapped. Tupý and Primot (1982) detected activity of Susy in the latex of the rubber tree but not of sucrose phosphate synthase. They also observed that under natural conditions, although lower than in the cleavage direction, sucrose synthesis by Susy might be significant. However, this was weakened by ethrel application to the bark. A reduction of the synthetic activity, followed by an increase in sucrose utilization and an increase of latex yield, could be observed before the treatment-induced rise of $\mathrm{pH}$ enhancing invertase activity.

Associated with the biochemical parameters responsible for latex production, the importance of the rubber tree bark is undeniable in this process, since it is the main component of the rubber tree trunk. Previous reports have suggested a relationship between sieve tube diameter and rubber production (Azzini et al., 1998).

This work investigated a possible relationship between activities of the enzymes invertase and Susy, and anatomical bark characteristics, with latex production in three clones of H. brasiliensis.

\section{MATERIAL AND METHODS}

This work was carried out with latex collected in January of 2003 from rubber trees growing at the Plant Physiology Sector of the Department of Biology, University of Lavras. Three different clones of rubber trees were utilized in this study: RRIM 600, Fx2261 and GT1. The plants were 16 years old and five trees were used a replicates for each clone. These plants were in the field spaced by $3.0 \mathrm{~m} \times 7.0 \mathrm{~m}$ and at the moment of bleeding, no stimulants were employed to enhance latex flow. After bleeding the latex was centrifuged at $40,000 \mathrm{~g}_{n}$ for $60 \mathrm{~min}$ at $4^{\circ} \mathrm{C}$, the fraction of serum C collected (Yeang et al., 1984) and the protein content determined (Bradford, 1976).

Invertase activity was assayed with $0.5 \mathrm{~mL}$ of $\mathrm{C}$ serum, $0.5 \mathrm{~mL} 0.3 \mathrm{~mol} / \mathrm{L}$ sucrose, $0.12 \mathrm{~mol} / \mathrm{L}$ sodium fluoride and $0.2 \mathrm{~mol} / \mathrm{L}$ phosphate buffer at $\mathrm{pH} 7.4$ for neutral invertase or 
$\mathrm{pH} 4.5$, for acidic invertase, at $30^{\circ} \mathrm{C}$ for $30 \mathrm{~min}$. The reducing sugars formed from sucrose cleavage were measured according Miller (1959). The replicates were made for each rubber tree from the three clones.

Activity of Susy was assayed in the direction of sucrose degradation (Déjardin et al., 1997). The reaction mixture contained $0.4 \mathrm{~mL}$ serum $\mathrm{C}, 64$ umoles MES buffer, $\mathrm{pH}$ 6.0, $125 \mu \mathrm{mol}$ sucrose, $0.5 \mu \mathrm{mol}$ of uridine diphosphate (UDP), in a final volume of $1 \mathrm{~mL}$. The reaction proceeded for $1 \mathrm{~h}$ at $37^{\circ} \mathrm{C}$ when the formation of reducing sugars was analyzed (Miller, 1959).

Serum $\mathrm{C}$ was also analyzed for its protein profile by denaturing electrophoresis (Sambrook et al., 1989). Equal amounts of protein of each sample were loaded on the polyacrylamide gels and the proteins were stained with Coomassie Blue.

For anatomical evaluations bark was cut at a height of about $1.50 \mathrm{~m}$ from the soil, and to the depth of the xylem. After collection, the barks were fixed in FAA. Transversal cuts were obtained freehand using a razor blade and sections were stained with astra blue and safranine. The numbers of lactiferous cells and lactiferous rings per $\mathrm{mm}^{2}$, as well as the lactiferous cell diameter were obtained under the microscope. Twenty-five fields were observed for each plant.

\section{RESULTS AND DISCUSSION}

Table 1 shows the yields of the three clones used in this study. It is evident that the clones have a marked difference in yield, which makes them suitable to study the relationship between rubber production and enzyme activities. These clones also showed marked differences regarding the anatomical characteristics (table 1). The evaluated characteristics were higher in the most productive clone RRIM 600. It is noteworthy that for these characteristics GT 1 did not accompany the intermediate value observed for latex yield.

Serum $\mathrm{C}$ is the aqueous medium of the rubber tree latex in which rubber particles and other organelles are present. According to Yeang et al. (2002), proteins in the latex make up about $1-2 \%$ of the fresh weight and a complex mixture of more 50 proteins may be detected by electrophoretic separation. About $25 \%$ of these proteins are bound to the surface of the rubber particles, including the enzymes required for rubber biosynthesis (Siler and Cornish, 1995).

Figure 1 shows the profile and the protein contents of serum C obtained from the latex of the clones RRIM 600, GT 1 and Fx2261. Among a group of five replicates, two plants of each clone contrasting in latex production were selected for protein analysis: high yield (R01; Fx01 and GT05) and low yield (R04; Fx05 and GT01). It was not possible to correlate latex yield with protein content (figure 1A) or electrophoresis profile (figure 1B). Clone GT05 did not follow the trend of the other two high yield clones which showed a higher protein concentration than the corresponding low yield clones. Additionally, although there were differences among clones for the protein profile, there was no difference between low and high yield clones. These differences might be expected and indicate genetic variability for the clones.

Although in great demand for the biosynthesis of rubber, a high content of sucrose in the latex may reflect poor metabolic utilization and consequently, a low yield (Jacob et al., 1988). Capacity to regenerate latex between two successive tappings seems to be highly dependent on sucrose availability (Jacob, 1970; Pujade-Renaud et al., 1994). After cleavage of sucrose to fructose and glucose these sugars are rapidly metabolized and their concentrations in latex do not necessarily reflect their importance (Yeang et al., 1984).

The activities of neutral cytosolic invertase (INC) and acidic vacuolar invertase (IA) were evaluated in the serum $\mathrm{C}$ of the rubber tree latex (figure 2). INC activity was higher than IA in all three clones but it was higher in the clones RRIM 600 and GT-1. IA activity on the other hand was highest in the RRIM 600 clone. Jacob et al. (1982) reported that a relationship between invertase in the latex and rubber yield indicates that factors modulating "in situ" enzyme activity might be important for the biosynthesis of rubber between bleedings.

Table 1. Average number of cells, lactiferous rings and sclereids per $\mathrm{mm}^{2}$, average diameter of the lactiferous cells, and latex yield in three rubber tree clones.

\begin{tabular}{lcccc}
\hline Clones & Yield (g.bleeding $\left.{ }^{-1}\right)$ & $\begin{array}{c}\text { Lactiferous cells } \\
\left(\mathrm{mm}^{2}\right)\end{array}$ & $\begin{array}{c}\text { Number lactiferous rings } \\
\left(\mathrm{mm}^{2}\right)\end{array}$ & $\begin{array}{c}\text { Diameter lactiferous cells } \\
(\mu \mathrm{m})\end{array}$ \\
\hline RRIM 600 & $46.60 \mathrm{a}$ & $126.96 \mathrm{a}$ & $4.12 \mathrm{a}$ & $34.38 \mathrm{a}$ \\
GT 1 & $23.32 \mathrm{~b}$ & $68.55 \mathrm{~b}$ & $2.45 \mathrm{~b}$ & $28.62 \mathrm{ab}$ \\
Fx 2261 & $4.72 \mathrm{c}$ & $47.64 \mathrm{~b}$ & $2.48 \mathrm{~b}$ & $27.36 \mathrm{~b}$ \\
\hline
\end{tabular}

Means followed by the same letter do not differ statistically by the Tukey test at $5 \%$ probability. 


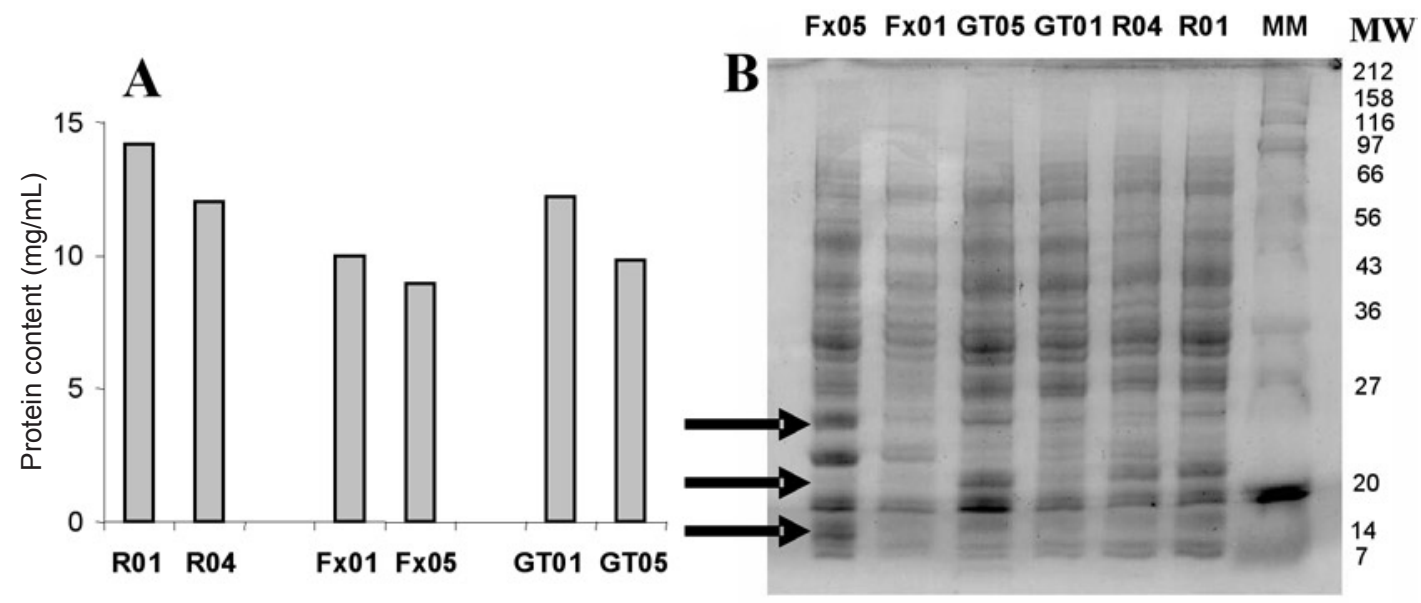

Figure 1. Total protein content in serum $\mathrm{C}$ of the rubber plant latex of three different clones (A) and protein electrophoresis profile (B) of two replicates of the clones RRIM 600 (R01 and R04), Fx2261 (Fx01 and Fx05) and GT1 (GT01 and GT05). The arrows indicate proteins which are contrasting among clones. $\mathrm{MM}=$ molecular markers; $\mathrm{MW}=$ molecular weight.

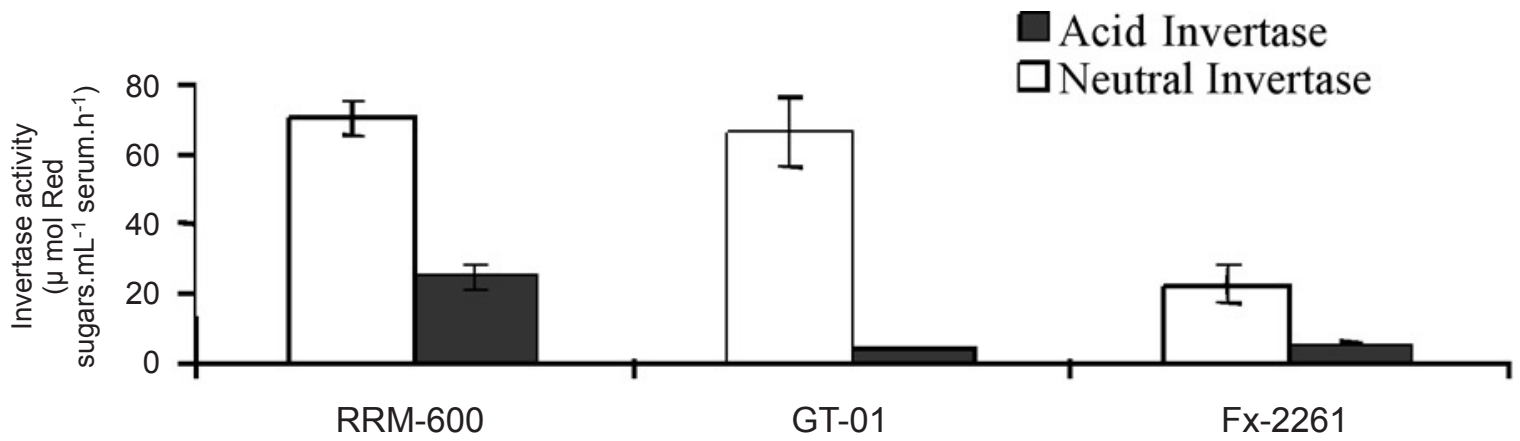

Figure 2. Neutral and acidic invertase activities in serum $\mathrm{C}$ of three rubber tree clones. Data are means of five replicates.

Kinetic parameters of invertase in the latex of rubber tree were investigated by Jacob et al. (1982). They observed that enzyme efficiency was $\mathrm{pH}$ dependent, being higher below pH 7.0 and decreasing markedly above it. It is well known that ethylene (released from Ethrel application) increases bleeding in tapped rubber trees, a process that is accompanied by an alkalinization of the latex (Amalou et al., 1992). Tupý (1973b) had previously observed an increase of latex invertase when rubber trees were subjected to treatments which increase latex yield, such as bark scraping, latex tapping, and bark application of 2,4-D or 2-chloroethylphosphonic acid (CEPA). Tupý (1973b) also observed that the activity of invertase was regulated by the latex $\mathrm{pH}$, which varied between 6.3 and 7.1, whereas the activity of invertase, as assayed directly in the latex, had a optimum at $\mathrm{pH} 7.5$, decreasing significantly at low pHs. CEPA and bark scraping were also shown to increase latex $\mathrm{pH}$ in tapped trees.
As for INC, Susy activity in the latex serum C was higher in the clones RRIM 600 and GT 1 than clone FX 2261 (figure 3), indicating the existence of a relationship between these two enzymes and latex yield (table 1), at least during the period of the year when the plants were evaluated. In contrast to our results, Yeang et al. (1984), who studied the activity of invertase during the cold months of the year, did not find a positive relationship with latex yield.

In a seasonal study, Oliveira (1999) detected higher invertase activities in the latex of clone RRIM 600 during the summer when plants presented greatest density of the crown, indicating that low activities during cold months might be related with the photosynthesis limitation at low temperatures and the stem growth activity. Latex production is also decreased by low temperatures during cold months (Melo et al., 2004).

Both Susy and invertase cleave sucrose to reducing sugars and their relative participation in the rubber tree latex still remains not fully investigated. Susy was assayed in the serum 


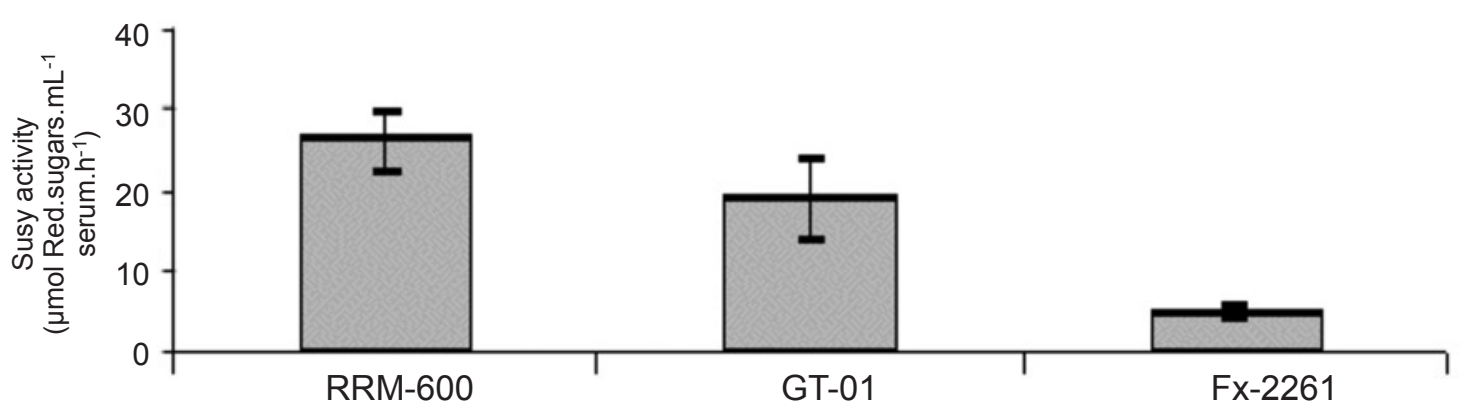

Figure 3. Sucrose synthase activities in serum $\mathrm{C}$ of three rubber tree clones. Data are means of five replicates.

$\mathrm{C}$ of rubber trees in the cleavage direction and by comparison with invertase data it was at least twice less efficient (figures 2 and 3) suggesting that invertase was the most effective enzyme for sucrose cleaving.

Tupý and Primot (1982) carried out a detailed study with Susy in the latex of the rubber tree. Sucrose phosphate synthase, an enzyme which may also lead to sucrose synthesis, was not detected. The purified enzyme had a reduction in cleavage activity with increased $\mathrm{pH}$. In the latex of regularly tapped trees, the total enzyme activity in the direction of sucrose synthesis was about $10 \%$ or less of the total invertase activity at pH 7.0. Tupý (1973b) reported that latex $\mathrm{pH}$ varies between 6.3 and 7.1 and that at $\mathrm{pHs}$ higher than 7 , invertase activity increased. Here, latex was obtained from plants that did not receive any application of ethylene (Ethrel) to stimulate latex production. However, Tupý and Primot (1982) observed that with hormone application there was a rise in latex $\mathrm{pH}$, which decreased Susy activity even further, while invertase activity increased with a consequent reduction of sucrose content.

In addition to biochemical metabolic aspects, it seems that anatomic characteristics are also related with latex yield in rubber plants. Ho et al. (1973) suggested that the number of lactiferous vessels is a character determining yield in adult rubber trees. According to Webster and Paardkooper (1989), the average number of lactiferous rings is the most import characteristic in the lactiferous system, increasing with age and being inherent to the clone genotype.

Azzini et al. (1998) showed the existence of a significant correlation between sieve tube diameter and rubber production. Besides lactiferous cell diameter, we also evaluated the number of lactiferous cells and the number of lactiferous rings per $\mathrm{mm}^{2}$ (table 1). Lactiferous cell diameter varied in the same range found by Azzini et al. (1998) who reported a mean value of $48.7 \mu \mathrm{m}$ for productive and $39.8 \mu \mathrm{m}$ for non-productive rubber trees. However, the intermediate productive clone GT 1 did not differ from the less productive Fx2261 clone indicating that such an anatomical difference might only be used as an indicator of productivity to distinguish clones at extremes of productivity. The same was observed for the number of lactiferous cells and lactiferous rings per area.

Therefore, from the invertase and anatomical measurements one may conclude that there is good evidence that together they might be used to identify highly productive rubber tree clones. This however should be tested in more plants to validate this hypothesis. Furthermore, it would be interesting to extend such a study to plants receiving Ethrel application, a common practice in the rubber tree crop.

\section{REFERENCES}

Amalou Z, Bangratz J, Chrestin H (1992) Ethrel (ethylene releaser)-induced increases in the adenylate pool and transtonoplast delta-pH within Hevea latex cells. Plant Physiol. 98:1270-1276.

Azzini A, Gonçalves PS, Tomaz RMAG (1998) O diâmetro do tubos crivados e a produção de borracha em clones de seringueira. Bragantia 57: available online http:// www.scielo.br/scielo.php?script=sci_arttext\&pid=S0006-8 $7051998000100008 \& \operatorname{lng}=$ en\&nrm=iso.

Bradford, MM (1976) A rapid and sensitive method for the quantification of microgram quantities of protein utilizing the principle of protein-dye binding. Anal. Biochem. 72: 248-254

Bouteau F, Dellis O, Bousquet U, Rona JP (1999) Evidence of multiple sugar uptake across the plasma membrane of laticifer protoplasts from Hevea. Bioelectrochem. Bioenerg. 48:135-139.

DéjardinA, Rochat C, Wuillém S, Boutin JP(1997)Contribution of sucrose synthase, ADP-glucose pyrophosphorylase and starch synthase to starch synthesis in developing pea seeds. Plant Cell Environ. 20:1421-1430.

Ho CY, Narayanan R, Chen KT (1973) Clonal nursery studies in Hevea: I. Nursery yields and associated structural 
characteristic and their variations. J. Rubber Res. Inst. Malasya 4:305-316.

Jacob J-L (1970) Particularité de la glycolyse et de sa régulation au sein du latex d'Hevea brasiliensis. Physiol. Veg. 8:395-411.

Jacob J-L, Prevot JC, D’Auzar J (1982) Physiological activators of invertase from Hevea brasiliensis latex. Phytochemistry 21:887-893.

Jacob J-L, Serres E, Prevot JC, Lacrotte R, Vidal A, Eschbach JM, D'Azuar J (1988) Mise au point du diagnostic latex chez l'hevea. Agritop 12:97-115.

Kush A (1994) Isoprenoid biosynthesis: the Hevea factory. Plant Physiol. Biochem. 32:761-767.

Melo RF, Oliveira LEM, Mesquita AC, Delú Filho N (2004) Variação sazonal de algumas características nutricionais e bioquímicas relacionadas com a produção de látex em clones de seringueira [Hevea brasiliensis (Wild.) Muell. Arg.)], em Lavras-MG. Ciênc. Agrotec. 28:1326-1335.

Miller GL (1959) Use of dinitrosalicylic acid reagent for determination of reducing sugar. Anal. Chem. 31:426-428.

Moraes VHF, Neto OGR, Seeschaaf KW (1978) Teores de sacarose no látex de seringueiras nativas estimuladas com ethrel. Pesq. Agrop. Bras. 13:27-34.

Nguyen-Quoc B, Foyer CH (2001) A role for 'futile cycles' involving invertase and sucrose synthase in sucrose metabolism of tomato fruit. J. Exp. Bot. 52:881-889.

Oliveira DP (1999) Avaliação sazonal da produção de látex e atividade de invertase em dois clones de seringueira (Hevea brasiliensis Muell Arg.), cultivadas em Lavras, Minas Gerais. Universidade Federal de Lavras, Lavras, $\mathrm{MG}, \mathrm{MSc}$ thesis.

Pujade-Renaud V, Clement A, Perrot-Rechenmann C, Prevot JC, Chrestin H, Jacob JL, Guern J (1994) Ethylene-induced increase in glutamine synthetase activity and mRNA levels in Hevea brasiliensis latex cells. Plant Physiol. 105:127-132.
Sambrook J, Fritsch EF, Maniatis EFT (1989) Molecular Cloning - A Laboratory Manual, $2^{\text {nd }}$ edn. Cold Spring Harbor, New York.

Siler DJ, Cornish K (1995) Measurement of protein in natural rubber latex. Anal. Biochem. 229:278-281.

Sturm A (1999) Invertases: primary structures, functions, and roles in plant development and sucrose partitioning. Plant Physiol. 121:1-7.

Tangpakdee J, Tanaka Y, Ogura K, Koyama T, Wititsuwannakul R, Wititsuwannakul D (1997) Rubber formation by fresh bottom fraction of Hevea latex. Phytochemistry 45:269-274.

Tupý J (1973a) The regulation of invertase activity in the latex of Hevea brasiliensis Muell. Arg.: the effects of growth regulators, bark wounding, and latex tapping. J. Exp. Bot. 24:516-524

Tupý J (1973b) Influence de la stimulation hormonale de la production sur le teneur de saccharose du latex d'Hevea brasiliensis. Rev. Gener. Caouthouc et Plastiques 50 :311314.

Tupý J (1988) Sucrose supply and utilization for latex production. In: D’Azuac J, Chrestin H (eds), Physiology of rubber tree latex. pp179-218. CRC, Boca Raton.

Tupý J, Primot L (1982) Sucrose synthetase in the latex of Hevea brasiliensis Muell. Arg. J. Exp. Bot. 33:988-995

Wardlaw IF (1990) The control of carbon partitioning in plants. New Phytol. 116:341-381.

Webster CC, Paardekooper EC (1989) The botany of the rubber tree. In Webster CC, Baulkwill WJ (Eds), Rubber. Pp.5784. Longman, New York.

Yeang HY, Low FC, Gomez JB, Paranjothy K, Sivakumaran $\mathrm{S}$ (1984) A preliminary investigation into the relationship between latex invertase and latex vessel plugging in Hevea brasiliensis. J. Rubber Res. Inst. Malaysia. 32:50-62.

Yeang HY, Arif SAM, Yusof F, Sunderasan E (2002) Allergenic proteins of natural rubber latex. Methods 27:32-45. 